\title{
PROFESSOR DANIEL GEORG BALK - THE FIRST ANTHROPOLOGY LECTURER AT THE REOPENED UNIVERSITY OF DORPAT (TARTU) IN 1802
}

Hoping to prevent the spread of the French revolutionary ideas to Russia, Paul I with his ukase of April 9, 1798 prohibited the subjects of Russia to attend West European universities. Together with the ban the Baltic knighthood were allowed to open a local university and select its location by mutual agreement. During the next three years both Dorpat (Tartu) and Mitau (Jelgava) made efforts to become a university town. The new Czar Alexander I appointed with his ukase of April 12,1801 Tartu the site of the university, substantiating his choice by its central location, favourable neighbourhood, and the fact that there had been a university before.

On April 21-22 the University of Dorpat (Tartu) was opened festively and on May 1 the only German Language University in the Russian Empire began its work with nine professors and 19 students [1].

The Faculty of medicine began its work with three professors instead of four [2] - Daniel Georg Balk (1764-1826) as Professor of pathology, semiotics, therapy, and the clinic, Martin Ernst Styx (1759-1829) as Professor of dietetics, public and popular medicine, and pharmacology, and Philipp Erdmann Heinrich Gottlob Arzt (?-1802) as Professor of chemistry and pharmacy [3]. The number of students was rather small - only six.

At that time the university did not have any established or compulsory curricula, the length of study was not fixed, the testing of knowledge was superficial and sporadic. In addition to the compulsory lectures, professors supervised students on an individual basis but seldom conducted any practicums. The faculty failed to meet the required academic standards, and there was a shortage of lecture halls. Both these factors caused serious problems during the first years after the reopening of the university because the student population increased eight times over a short period of time [1].

Of the three first professors of the Medical faculty Daniel Georg Balk was certainly the most outstanding one. He was born in Königsberg in the family of an amber polisher on June 23,1764 . He got his first education at home and at school [4]. 
In the years 1780-1787 he studied at the Medical faculty of Königsberg University (working meanwhile in Berlin). In 1787 he earned his doctorate of medicine at the same university. His dissertation studied irritants of skin and the mucous membrane.

He then practised medicine in Courland and Lithuania. In 1796 he was appointed district physician of Jakobstadt (Jēkabpils). On June 28, 1799 Balk became the doctor of Baldone Health Resort, which is located $33 \mathrm{~km}$ from Rīga. The numerous medical books that he wrote during this period point out the drawbacks of health service emphasise the need to protect one's health and the social significance of health. In his opinion, the training of physicians at local universities would give better results than studying abroad.

Balk's proposals concerning the health service had a reformation character and were progressive for his time. In addition, Balk revealed a literary genius, and he took a deep interest in theatrical art as well. His fame was increased by the measures that he took against the cattle plague that ravaged the entire Courland at the turn of the century. Because of this he was invited to become the first professor of pathology, semiotics, therapy, and the clinic at the University of Dorpat (Tartu) in 1802.

Professor Balk became actively involved in the development of the university. A number of his speeches drew attention to the human being, educational problems, and the physical and intellectual development of a human being [6]. During the first semester, which lasted only for two months, Prof. Balk taught pathology, the laws concerning longevity, and medical methodology [3]. Already beginning with the second semester of the same academic year, which began on August 1, Prof. Balk's list of courses includes as number one lectures on medico-philosophical anthropology for medical students - four times a week, one hour each time [7].

His lectures were based on the textbook "Medico-philosophical anthropology for doctors and non-doctors" by Professor Johann Daniel Metzger (1739-1805), physician in ordinary to the Prussian king, privy councillor, and professor of Königsberg University. This publication served as the recommended textbook for giving academic lectures. The book consisted of an introduction and six chapters. For its time the first chapter gave a thorough overview of the descent of man. The chapters followed it on medical psychology, physiology, dietetics, pathology and therapy [8].

Prof. Balk's lectures on medico-philosophical anthropology were followed by lectures on general pathology. In addition, he lectured on the influence of galvanic electricity on living and dead animals by applying an experimental method. He may have been the first lecturer in the Russian Empire to illustrate his teaching with experiments.

As the professor of anatomy had not arrived as yet, he taught also osteology together with a demonstration of bone preparations [7]. 
During the autumn semesters of the next two years Professor Balk taught physico-philosophical anthropology as a preparatory course for purely philosophical anthropology. He then taught during one autumn semester natural historical and philosophical anthropology as a prerequisite for purely philosophical anthropology.

During the spring semesters of 1807 and 1808 Prof. Balk taught physiologicphilosophical anthropology as an introduction to philosophical anthropology. All the above-mentioned lectures were taught with the same number of hours and according to the above-mentioned textbook [9].

This concluded Prof. Balk's lectures on anthropology. However, he kept working at the Faculty of medicine until June 5, 1817. The list of Prof. Balk's lectures is not short. He taught general and special pathology, semiotics, health science, and medico-philosophical law to law students according to his own study aid [9]. It is known that he had claimed as early as in 1795 that each judge should know forensic medicine, police medicine, and anthropology and should pass examinations in these subjects before taking office [6]. Moreover, he used to teach general therapy, casuistic medicine, gynecological diseases, special pathology and therapy of children's diseases and fever, suspended animation, such diseases that may result in sudden death, the art of writing out prescriptions, venereal diseases, treatment of chronic skin diseases, pathology and treatment of mental diseases, introduction to surgery, surgery, methodology and medical encyclopaedia; he supervised clinical work [9]. As the second Rector of the University of Dorpat (Tartu) (from August 1, 1803 through August 1, 1804) and the four-time dean of the Medical faculty $(1804,1808,1811$, and 1815) Prof. Balk made an important contribution to the development of the Medical faculty. He was actively involved in the construction of the so-called old Anatomical Theatre. The foundation of this building was laid 195 years ago on June 3,1803 . In addition, he was involved in the construction of the clinic [10]. In the first half of 1804 Professor Balk introduced clinical practicums to the curriculum. On May 1 of the same year he opened the first-ever polyclinic in the then Russian Empire, which applied rudiments of serving the population according to the territorial principle. In 1808 he set up the first aid station in Russia. $\mathrm{He}$ also set up an institution that was affiliated to the hydrotherapeutic institution and clinic to train nurses. Professor Balk did a lot to treat the sick and wounded soldiers both in 1807 and 1812-1813 [6].

Professor Balk's diligent work was appreciated by three valuable diamonds rings [11]. He can be regarded as an outstanding physician in the Baltic's at the end of the $18^{\text {th }}$ and the beginning of the $19^{\text {th }}$ century. The world-renowned naturalist Karl Ernst von Baer wrote his dissertation "About the endemic diseases of Estonians" (1814) at Prof. Balk's suggestion [12]. Because of the description of the physique and appearance of Estonians this work could be regarded as an anthropo-medico-geographic study. Prof. Karl Friedrich Burdach (1776-1847) has claimed that most dissertations that were written at the 
Medical faculty of Tartu University during the first 15 years included Balk's views. In addition, at the turn of the century Prof. Balk had tried to develop a theory the main idea of which had a material and chemical character and was supplemented by his views of the excitation theory [6].

Unfortunately, we do not have any photographs of Prof. Balk. Johann Wilhelm Krause (1757-1828), Professor of Agriculture, Technology, and Architecture, described him as a man of noble appearance with beautiful features and of slender build. He is said to have been characterised by knowledge of life, wittiness, sense of humour, and ease at work [10].

Because of his uncompromising character he had a number of arguments with Prof. Georg Friedrich Parrot (1767-1852), rector of University for several terms, and some professors of the Medical faculty. In his later years at the university he began to spend more time in Musse, drinking and gambling there. All this, including his participation in theatrical performances, served as a reason for accusing Prof. Balk of immorality. In 1817 at the age of 53 Balk was forced to leave the university, whereby he lost the advantages for himself and his children which were foreseen by the foundation charter of the university. Balk went to Tula; he died there early in 1826. One of his daughters got married to N.Chr. Rinne, district physician for Paide. The other family members also moved to Paide, where they lived in poverty. It was as late as 1830 when he was entitled to a pension. Until now it has been written that Prof. Balk had made important contributions to the development of popularisation of hygiene in the Baltics, the development of clinical medicine in Tartu, and the development of polyclinical medicine in Russia [6]. We are the first to study his lectures on medico-philosophical anthropology (at times physical, natural, or physiologic-philosophical anthropo$\operatorname{logy}$ ) that he taught in the years 1802 through 1808 . And we are going to ask when was the teaching of anthropology started in the other older universities of Czarist Russia. At Moscow university (the oldest university of Czarist Russia), Ivan Fyodorovich Vensovitch (1769-1811), Professor of anatomy, physiology and forensic medicine, reported for the first time about the need to teach anthropology at Moscow university in his festive speech of 1805 to celebrate the $50^{\text {th }}$ anniversary of the university [13].

By then in Tartu anthropology had been taught for three years already. The year 1805 could still be considered as a peak year of teaching anthropology at the University of Dorpat (Tartu) because at that time there were four professors in the Medical faculty who were dealing with it - D. G. Balk, Heinrich Friedrich Isenflamm (1771-1825), M. E. Styx, Ludwig Emil Cichorius (1770-1829). They were teaching five different courses on anthropology or courses that included elements of anthropology [14]. The other older universities of Czarist Russia were restored or established after the reopening of the University of Dorpat (Tartu) in 1802 [15]. Thus one could state that the lectures of D.G.Balk, Professor of pathology, semiotics, therapy, and the clinic, in the second half of 1802 were the first anthropology lectures in the universities of Czarist Russia. 


\section{References}

1. Tartu Ülikooli ajalugu: II. - Tallinn, 1982.

2. Statuten der Kaiserlichen Universität zu Dorpat, nach Anleitung des am 4. Mai 1799 Allerhöchst konfirmierten Planes, nebst den namentlichen Befehl Sr. Kaiserl. Majestät am 5. Januar 1802 hinzugekommen Veränderungen. - Dorpat, 1802.

3. Anzeige der Vorlesungen welche auf der Kayserlichen Akademie zu Dorpat vom 1 May bis zum 1 Julius des Jahres 1802 gehalten werden. - Dorpat, gedruckt bey Michael Gerhard Grenzius, Universitäts-Buchdrucker.

4. Album rectorum Universitatis Tartuensis 1632-1997. - Tartu, 1997.

5. Normann H. Katkend Tartu Ülikooli arstiteaduskonna algetest // Eesti Arst. 1925. - № 11. - Pp. 323-332.

6. Kalnin V. Daniel Georg Balk // Eesti arstiteaduse ajaloost. - Tartu, 1996. Pp. 25-29.

7. Verzeichnis der Vorlesungen auf der Kayserlichen Universität in Dorpat, für gegenwärtiges Semester, vom 1 August, bis Ende December des Jahres 1802. Dorpat.

8. Metzger J. D. Medizinisch-Philosophische Anthropologie für Aerzte und Nichtaerzte. - Leipzig, 1790.

9. Verzeichnis der haltenden Vorlesungen auf der Kaiserlichen Universität zu Dorpat: 1803-1817. - Dorpat.

10. Krause J. W. Kunagise Tartu ülikooli esimene aastakümme // Mälestusi Tartu ülikoolist (17.-19. sajand) / Koostanud Sergei Issakov. - Tallinn, 1986. Pp. 60-66.

11. Левичкий Г. В. Биографический словарь профессоров и преподавателей имп. Юрьевского, бывш. Дерптского университета (1802-1902). - Юрьев, 1903. - T. 2. - C. $112-115$.

12. Kaavere $V$. Baer. - Tartu, 1992.

13. Залкинд Н. Г. Московская школа антропологов в развитии отечественной науки о человеке. - Москва, 1974. - С. 18.

14. Kasmel J., Erits H. About teaching anthropology at the University of Dorpat (Tartu) in the first of the $19^{\text {th }}$ century // Papers on Anthropology. - Tartu, 1997. VIII. - Pp. 181-187.

15. Koop A. Tartu Ülikool 350. - Tallinn, 1982.

\section{Jaan Kasmel, Tiiu Kasmel}

Centre for Physical Anthropology University of Tartu

Lossi 36, Tartu EE 2400, Estonia

E-mail: jaanjkasmel@hot.ee 
